\section{Lakis Pavlou}

heads the national foodstore and retail warehouse team at GVA Grimley and has 13

years' agency experience in the out-of-town retail market.

Lakis has been involved in a number of foodstore

transactions acting for

foodstore operators such as

Tesco, Asda and Waitrose as

well as vendors such as local authorities and developers. He was also involved in the huge

Do It All disposal programme in the late 1990s which

encompassed the disposal of over 186,000m ${ }^{2}$ of space. On the asset management side Lakis now manages a number of retail parks on behalf of institutional/property company landlords.

\section{Keywords}

leases, warehouse retailing, landlord, tenant, retail parks, DIY
Lakis Pavlou

GVA Grimley

10 Stratton Street

Mayfair

London W1] 8JR, UK

Tel: +44 (o)20 79112153

Fax: +44 (o)20 79112560

E-mail: lakis.pavlou@gvagrimley.co.uk

\section{The 25-year leases of the first wave of retail warehouse developments in the UK are about to expire: What will be the impact on the sector?}

\author{
Lakis Pavlou
}

Received: 14 March 2003

\begin{abstract}
The paper looks at the factors that come into play on lease expiries for retail warehouses from a tenant's, landlord's and town's perspective. It examines how modern retailing requirements and the current planning regime for out-of-town retail space impact upon the tenant's and landlord's decisions.
\end{abstract}

\section{INTRODUCTION}

The first retail warehouses in the UK were developed in the late 1970s. In the early days the majority of these comprised stand-alone DIY/furniture stores, with the competition in the DIY sector driving the retail warehouse market forward at that time. There were seven national DIY retailers competing for space in the 1980s, namely B\&Q, WH Smith's Do It All, Payless DIY, Texas

Homecare, Homebase, Great Mills and Wickes. With the exception of Wickes, they all had similar standard requirements for stores of circa $3,300 \mathrm{~m}^{2}$, together with $900 \mathrm{~m}^{2}$ for garden centres. In the furniture sector the race for space was between Harris Queensway and MFI, with requirements for stand-alone retail warehouses of $2,800-3,700 \mathrm{~m}^{2}$.

In the early days the original units were predominantly built in industrial areas, which would now be described as secondary locations. As the market developed, however, operators demanded more high-profile locations and the next generation of units were built on prime arterial routes in out-of-town locations. As the popularity of out-of-town retail shopping grew, the number of retailers seeking space expanded. This led to the emergence of the first retail parks - typically three or more retail warehouse units grouped on the same site.

These original retail parks tended to have a similar tenant mix, with the vast majority anchored by a DIY retailer, followed by a furniture retailer, with carpet and electrical retailers taking the remaining units. The electrical retailing sector was extremely competitive following the privatisation of the former electricity 

Inside or outside of
the Act

\section{Stay or go}

boards. These retail park schemes were predominantly bulky goods led, although the planning consents granted at the time tended to be unrestricted, open A1/non-food consents.

In order to understand fully the impact on the sector now that the original leases are coming to an end, one needs to examine what the impact will be on the existing tenants, the landlords and the towns in which the parks are located.

\section{IMPACT ON THE TENANT}

The impact on the tenant largely depends on whether the existing lease is inside or outside the 1954 Landlord and Tenant Act. If the lease is inside the Act then the tenant will be entitled to a new lease upon expiry of their existing lease. But if the lease is outside the Act then the tenant will not have any rights of renewal. From the author's experience, the vast majority of leases were inside the Act, therefore most tenants will have the right to ask for a new lease.

There are a number of factors tenants need to consider when deciding whether to renew a lease on an existing property, including the following.

- Is the current store profitable and will it continue to be so?

- Is the location of the unit good enough to warrant taking a new lease?

- Is there another site within the town where a higher level of trade could be achieved, and has the pitch within the town changed?

- How does the current level of rental values for the existing store location compare to other locations in the town?

- Are there any possibilities for trade-off benefits by locating close to another retailer in the town?

- Which is likely to be the more successful location - on a retail park or a stand-alone location?

- Is the current specification of the unit suitable for today's modern retailing requirements?

- Are the fixtures and fittings within the existing unit beyond their economic life and do they need replacing?

- Would the landlords be prepared to refurbish the external façades to make the location more appealing?

- What incentives could the tenant negotiate with the landlord to take up a new lease?

- What length of lease would be most suitable?

Once the tenant has weighed up all the relevant factors, they can make an informed choice on the renewal of their lease.

\section{IMPACT ON THE LANDLORD}

The landlord's perspective on the expiry of a tenant's lease is very different. As the length of a tenant's lease reduces so does the investment value, as the length of the guaranteed income stream 
reduces. Losing a tenant on lease expiry will result in a loss of rental income unless a new tenant is found. Therefore, landlords need to plan ahead, and to have a future strategy in place.

Typically, landlords will start to consider their options up to three years before the expiry of a tenant's lease, and will examine a number of factors when preparing the future strategy.

- What are the possibilities of finding a new tenant who would be prepared to pay an open market rent on the premises? Would a refurbishment of the premises increase the chances?

- Will any prospective tenant be willing to take a 25-year lease on the old unit?

- What will be the covenant strength of any potential tenant?

- Is there a lack of retail planning consents in the town? What is the current planning consent? Is it bulky, open A1/non-food or open A1? Could the planning consent be widened or larger units subdivided to provide more flexible space?

- Are there any external matters that may affect demand, ie a new bypass, proposed new retail park development, etc?

\section{IMPACT ON THE TOWN}

If the leases are due to expire on a number of units within a town, the impact will depend on the provision of existing retail warehousing, whether there are any proposed developments and the nature of the planning consents on floorspace.

For example, if the retail warehouses are in secondary locations in a town where there is an oversupply of space, the prospect of being able to find new tenants will be limited. If existing tenants decide not to renew and new tenants cannot be found, there could be a loss of retail space. This could lead to a loss of competition in particular retail sectors, thereby reducing consumer choice.

Alternatively, if there is a limited supply of retail warehouse space in a town, prospective tenants are more likely to consider older space in order to gain representation. If tenants decide to relocate, this can alter the main retail warehouse pitch, which will change the town's shopping pattern. Landlords may also be able to capitalise on historic open A1 consents to regenerate bulky goods schemes into the next generation of shopping parks.

\section{PLANNING}

The current planning environment will play a role in determining the impact of lease expiries on the retail warehousing sector. The ability of landlords to widen current planning consents on units/ parks, or to undertake complete redevelopment works, will be dependent on planning policy.

PPG 6

The government is shortly due to publish a revised planning policy guidance (PPG) 6 which will set out policy for out-of-town retail. Following the recent decision to investigate the impact of retail planning curbs on UK competitiveness, it was hoped that the 
Class of goods approach revised PPG 6 might include a relaxation of government policy on out-of-town retail. However, a number of recent planning appeals, as illustrated below, have left developers and retailers expecting the worst.

The first such case is the Secretary of State's refusal of permission for an out-of-centre B\&Q warehouse development at Colchester following a call-in inquiry. The Secretary of State concluded, contrary to the recommendations of the inspector, "that there was no qualitative need for the scheme and that the sequential test had not been applied rigorously'.

The Secretary of State did not dispute the quantitative need argument, but rejected the inspector's conclusions of a demonstrative qualitative need. He concluded that 'this type of initiative was not an effective form of bulky goods retailing as many retailers offer a similar sort of facility albeit on a smaller scale'.

Another example is the Standard Life call-in inquiry in Croydon, where the Secretary of State refused an application for $4,200 \mathrm{~m}^{2}$ of retail warehousing. The application was unopposed and the inquiry inspector had recommended planning consent be granted. In refusing planning permission the Secretary of State concluded that:

\section{'the adopted Development Plan did not reflect the guidance in PPG 6 in that evidence of need must be demonstrated and the sequential test must be applied to new retail developments outside of town centres. The fact that PC World may have been one of the occupiers and the fact that there was pressure for more retail warehousing in Croydon was not evidence of need, as many of the items to be sold were not bulky in nature.'}

This highlighted the difficulty in the application of a 'class of goods' approach to the sequential test, rather than a format-driven approach. The very fact that most bulky goods retailers also sell a number of their goods as part of an overall offer questions the 'class of goods' approach. Unfortunately, different interpretations of the approach have been reached with various appeal cases.

The Croydon decision shows that the way goods are sold is as important as the type of goods sold, and may be material to the sequential tests for a planning application.

More recently, the decision by the ODPM (Office of the Deputy Prime Minister) to turn down an application by IKEA will have significant consequences. The proposal for the store was blocked by the ODPM, despite the planning inspector's recommendation that it be approved. The ODPM insisted this time that the retailer should look to sell its product 'in a reduced or disaggregated form', thereby conflicting with Ikea's emphasis on large warehouse units offering a full line of stock. IKEA subsequently appealed to the High Court and, because the ODPM has decided not to contest the appeal, it will now have to redetermine its decision. 
Car parking conundrum

Mezzanine floors
While most commentators believe this could herald a change, it is thought likely that the ODPM will reject the application and probably impose more stringent tests in the revised PPG 6 .

The impact of a more stringent PPG 6 will probably result in fewer first-generation schemes being redeveloped into modern retail schemes, as the locations may not satisfy current planning guidelines. Where planning consent is forthcoming, there may be restrictions imposed on the type of goods, as local authorities seek to turn open A1 consents into bulky goods consents.

The schemes originally built in the early 1980s benefited from more generous car-parking allowances that can be obtained in the current planning climate. Congestion and pollution were not such major issues at that time, and developers were often able to secure car-parking ratios of one space per $9 \mathrm{~m}^{2}$ for a food store and one space per $18 \mathrm{~m}^{2}$ for non-food retailing. In today's planning climate the adopted PPG 13 standards are one space per $14 \mathrm{~m}^{2}$ for food retail and one space per $20 \mathrm{~m}^{2}$ for non-food retail.

Car parking is such an important issue because it is the very crux as to why retail warehouse shopping has taken off. Consumers prefer to use free surface-level car parks on major routes, as opposed to paying to use multistorey car parks in congested town centres.

The greater the number of car-parking spaces on a park, the greater the potential for trade to be increased. For instance, it has now reached the stage on certain shopping parks in the UK where at peak times car parks are filled to capacity. Retailers cannot physically take any more money through the tills (excluding putting up prices) because the car parks are so busy that not enough people can get in or are often dissuaded from returning if they have a particularly bad experience.

If a landlord just intends to refurbish existing space at the end of an existing lease, then the extra car parking available will make the site more attractive to potential retailers. But if the landlord intends to redevelop space then the new PPG 13 guidelines will have to be adhered to, which will reduce the number of car-parking spaces. This may have a beneficial effect by allowing a higher density of development to occur than is currently found on the site.

\section{FLEXIBILITY}

Upon lease expiry, whether through redevelopment or refurbishment, it is important that landlords create flexible units which make an efficient use of space. For instance, the eaves height of retail warehousing has been increasing as more and more retailers are now turning towards mezzanine trading floors, because of the rise in rental values. Twenty-five years ago the majority of retail warehouse units were built to an eaves height of circa $5 \mathrm{~m}$. Today eaves heights of $6.5-7 \mathrm{~m}$ are more the norm, with some retailers requiring up to $8 \mathrm{~m}$.

Whether the landlords or tenants have the ability to install 


\section{Two-storey stores}

\section{Mixed-use schemes}

trading mezzanine floors depends on the existing planning consent, ie whether they are expressly prohibited or if there is a condition limiting the floor area on any one scheme. If not, both landlords and tenants are free to install trading mezzanine floors in their units, which has the potential effect of increasing retail floorspace by up to 75 per cent.

With planning consents becoming harder and harder to secure there could be the potential to redevelop certain first-generation sites to create two-storey trading units. B\&Q was the first DIY retailer in the UK to trial this concept at its Sutton store, which appears to be successful. B\&Q is now looking at a second twostorey store in Bournemouth, with three more in the pipeline at New Malden, Edgware Road and Sidcup.

In London, developers and retailers are being forced to take on mixed-use schemes, instead of the usual box retail unit. Developers have included social housing, by putting residential units above stores, as a way to get planning consent. Halfords currently trades from such a unit in Sutton where it has 16 apartments above the store. The days of the tin sheds have gone, and the sector has moved on and is adopting innovative new solutions.

The ultimate solution on any lease expiry is to recycle retail parks, and this has been done in a number of instances throughout the country. The challenge is to upgrade existing retail parks to meet modern retail needs. Land Securities has been successful in doing this at Cheetham Hill in Manchester, where it has redeveloped a first-generation bulky goods retail warehouse park into a stand-alone Big W unit. Pillar has also been successful in turning predominantly bulky goods retail parks nearing the end of their useful life into modern shopping parks, thereby taking advantage of the historic open A1 consents. It has been particularly successful at New Mersey Shopping Park, Liverpool and DeepDale Shopping Park, Preston.

The author believes that, as more leases expire on retail parks, the next wave will be 'goods' focused. As retail warehouse rents continue to rise, the bulky goods retailers will be forced out of the prime retail parks into 'goods parks'. These will comprise retailers typically selling the same type of goods, who want to be situated next to each other to offer consumers a one-stop shopping visit. Overall, the impact on the sector is expected to be positive, as retailing is constantly evolving to ensure it offers consumers what they want, but at the same time benefiting all parties. 